\title{
Global Classroom \\ - videokonference i undervisning
}

\section{Flemming Nielsen}

Cand. Techn.Soc.

HR- og udviklingskonsulent i VUC Storstrøm

Flemming Nielsen er uddannet på Tek-Sam på RUC i 1991 og arbejdede i først med regional erhvervs- og arbejdsmarkedsudvikling. Siden 2006 arbejdet med udvikling af pædagogiske kompetencer, bl.a. som projektleder for ITpædagogiske udviklingsprojekter hos VUC Storstrøm og Videncenter for anvendt IKT. 


\section{Abstract}

Efter fem år med anvendelse videokonference i undervisning gør VUC Storstrøm status for udvikling og implementering af den nye IKT-baserede læringsplatform . Visionen peger i retning af yderligere digitalisering og satsning på kvalitetsudvikling og fleksibilitet via investeringer i teknologi og kompetenceudvikling. Siden 2011 har VUC Storstrøm anvendt tilrettelæggelsesformen Global Classroom, som giver studerende mulighed for at vælge frit mellem fysisk tilstedeværelse og tilstedeværelse via individuel videokonference hjemmefra eller et andet eksternt lokale. I artiklen redegøres for baggrund og formål, forudsætninger for indførelse af fleksibel videokonference i klasseundervisning, samt for udbyttet for de studerende og underviserne. Artiklen er baseret på interne evalueringer, to artikler fra forskere på Aalborg Universitet, indtryk fra et speciale fra IT-U / Aalborg Universitet, samt forfatterens egne iagttagelser som projektleder i organisationen.

After five years of using videoconferencing in teaching the Adult Education Centre Storstroem (VUC Storstroem) looks back on the development and implementation of the new ICT based learning platform. The vision suggests further digitization and focus on quality and flexibility through investment in technology and skills. Since 2011 VUC Storstroem has used a didactic organization called Global Classroom which gives students the opportunity to choose freely between physical presence and presence through individual video conference from home or another remote site. This article explains the background and purpose and the preconditions for the introduction of flexible video conferencing in classroom teaching, as well as the benefits for the students and teachers. The article is based on internal evaluations, two articles from researchers at Aalborg University, impressions from a thesis from the IT-U / Aalborg University, and author's own observations as a project manager in the organization.

\section{Indledning}

Siden 2008 har VUC Storstrømi anvendt videokonference i undervisning. Vi har samtidig udviklet egen teknologisk platform og to nye tilrettelæggelsesformer: Parallelundervisning og Global Classroom, som begge præsenteres i næste afsnit. Det sker som et bevidst valg, dvs. en del af bestyrelsens og ledelsens strategi for fremtidens VUC Storstrøm. I udgangspunktet var vi problemorienterede - vi ville bidrage til at løse problemer som opstår i vores region, hvor befolkningstætheden er lille og betingelserne for rentabel drift af et stort udbud af uddannelse er dårlige. Med videokonference kunne vi binde vores afdelinger sammen, vi kunne binde klasselokaler sammen og opnå rentable holdstørrelser. Dermed kunne vi nå studerende, som vi ellers ikke kunne tilbyde undervisning. Det var starten, og det er fortsat et væsentligt grundlag, en væsentlig motivation. Men nu indgår videokonference også som et element, en 
rammebetingelse, der ud over at give flere kursister adgang til uddannelse også skal give flere motivation til at gennemføre deres uddannelse. Desuden slal de nye tilrettelæggelsesformer fremme IT-pædagogisk udvikling på VUC Storstrøm. Det har været en interessant og meget udfordrende proces, og jeg vil med denne artikel dele vores erfaringer, og give andre i uddannelsessektoren indblik i fordelene ved denne form for IT-pædagogik, og opmærksomhed på de udfordringer man helt sikkert løber ind $\mathrm{i}$.

Når vi anvender videokonference i undervisning, synkron e-læring, bliver undervisningen udfordret mere grundlæggende end vi er vant til, når vi indfører andre og mindre e-læringselementer. Med videokonference bliver undervisningens fysiske ramme åbenlyst ændret, men hele undervisningssituationen bliver også ændret, og indirekte sætter vi spørgsmål ved den konventionelle undervisning i et almindeligt klasserum. Det er en uhyre vanskelig proces, og vi har reflekteret over, hvorfor vi som system og individer i systemet har så vanskeligt ved at arbejde med denne form for forandringer. Det vender jeg tilbage til lidt senere.

Vi samarbejder med IT-Læring og Design, Aalborg Universitet, bl.a for at blive klogere på, hvordan synkron e-læring påvirker de studerendes udbytte af undervisningen. Vi ved, at interaktionen i klasserummet bliver anderledes; underviserens facilitering og ledelse af undervisningssituationen bliver anderledes; udviklingen af relationer bliver anderledes osv. Men hvad skal vi gøre for at det "anderledes", forandringen, bliver til positiv udvikling, dvs. et bidrag til de studerende læring og til undervisernes arbejdsmiljø? Det arbejder vi videre med, og hvordan vi gør det præsenteres sidst i artiklen.

\section{Introduktion til VUC Storstrøm, parallelundervisning og Global Classroom.}

VUC Storstrøm har afdelinger i syv byer i Sydsjælland, på Falster og på Lolland med i alt ca. 5500 studerende indskrevet hvert år på kortere og længere uddannelser, svarende til ca. 1400 årsstuderende. I 2008 indførte vi parallelundervisning, hvor lokaler i to afdelinger bliver koblet sammen via et videokonferencesystem. I 2013 har fem afdelinger hvert et lokale, og en afdeling har to lokaler til parallelundervisning, samt et lokale til almindelig videokonference. Desuden har afdelingerne mødelokaler med videokonference. I parallelundervisning, hvor én underviser har studerende i to lokaler, har vi tilstræbt, at oplevelsen bliver et fælles lokale. Dvs. at de respektive lokaler bliver forlænget med det parallelle lokale. Det grundlæggende set-up er et Polycom videokonferenceanlæg med mikrofoner, lydanlæg, to kameraer, en interaktiv tavle og to projektorer/projektorskærme i hvert lokale (Figur 1). 


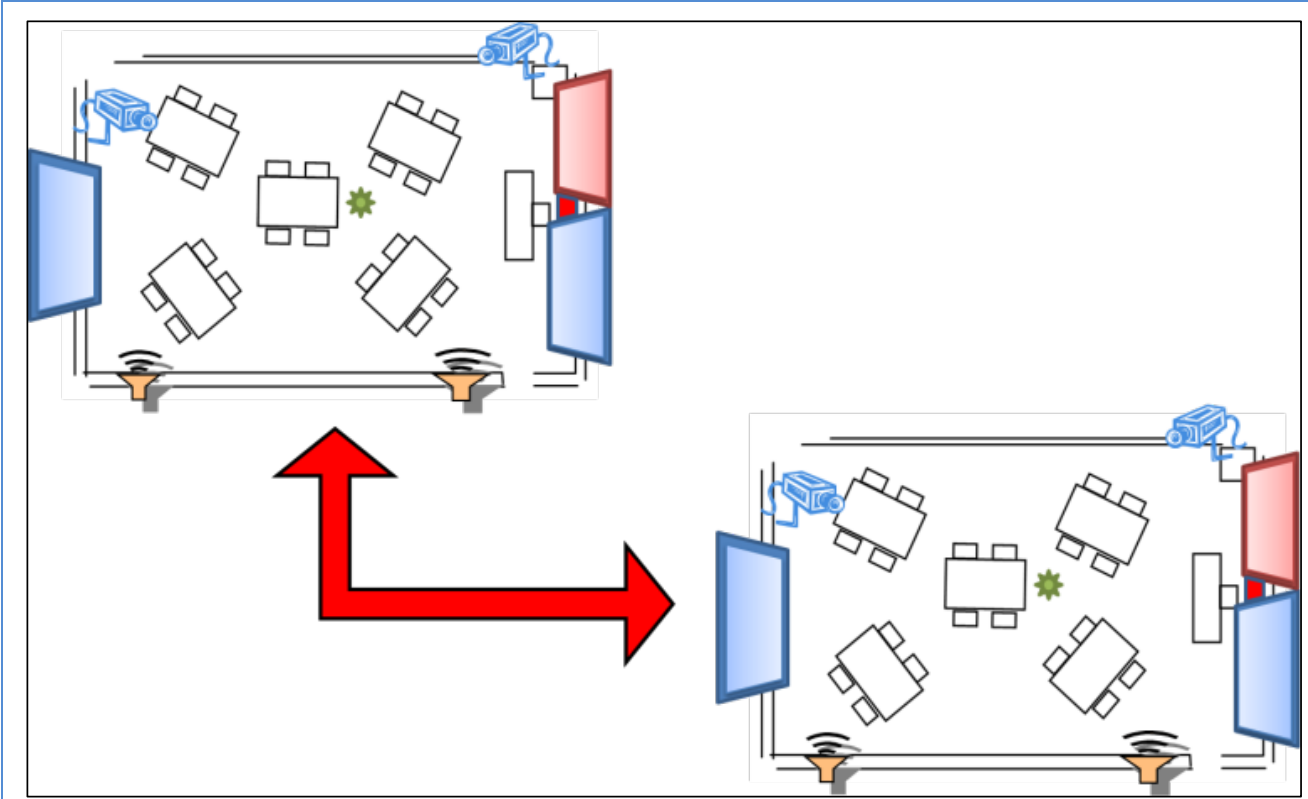

Figur 1. Parallelundervisningslokaler.

De to videoskærme og to kameraer i begge lokaler kan styres af underviseren fra et af lokalerne med enkle tryk på et kontrolpanel (Crestron). Vi har valgt projektorer fordi det giver mulighed for afbildning i fuld størrelse.

Fra den første forsøgsvise opsætning er der foretaget ændringer i det teknologiske set up, og nogle lokaler er også ændret med hensyn til den fysiske indretning i forhold til støjdæmpning og styring af lysindfald på kameraer og skærme.

I 2011 startede VUC Storstrøm implementeringen af en ny læringsplatform, med egne konferenceservere, som giver mulighed for, at op til 90 enheder samtidig kan interagere i videokonference. På denne platform har vi udviklet Global Classroom konceptet (figur 2), hvor studerende kan deltage i undervisningen hjemmefra på lige fod med studerende, der vælger at møde frem i undervisningslokalet. 


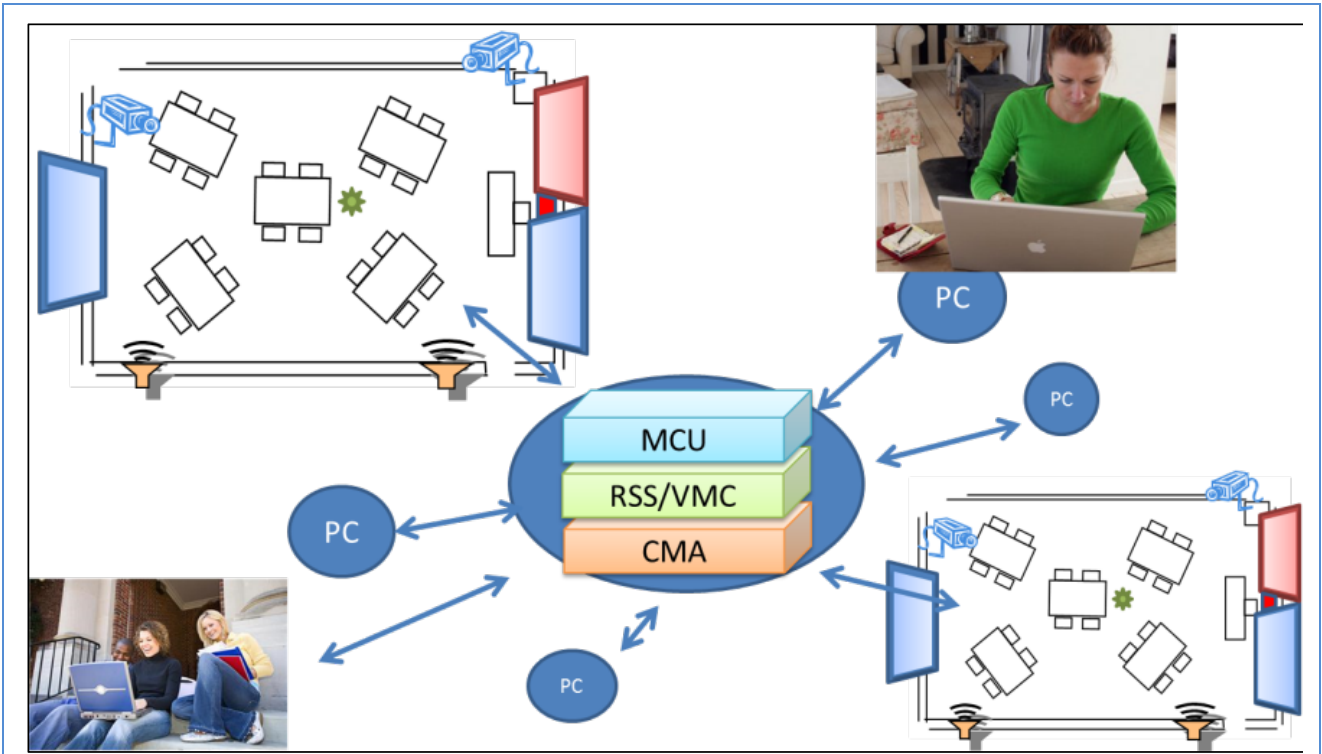

Figur 2. Global Classroom - se også dette link.

Der er senest i 2013 foretaget omfattende ændringer af skolens netværk og ikke mindst en stor opgradering af båndbredden på internetforbindelsen og netværket mellem afdelingerne for at imødekomme behovet for gnidningsfri kommunikation via videokonferenceserverne.

Efter de første år med parallelundervisning foretog vi en intern evaluering, hvorunder vores undervisere og IT-stab bl.a. reflekterede over, hvilke vigtige forhold man skal forholde sig til ved anvendelse af videokonference i undervisning. Vi evaluerer løbende på undervisningen i Global Classroom setup og kan se, at anbefalingerne fra erfaringerne med parallelundervisning også er relevante for dette setup:

- Underviseren bliver det sociale bindeled mellem de to lokaler / lokalet og de hjemmesiddende studerende.

- Underviseren skal gøre en ekstra indsats for at opbygge relationer til studerende i alle lokaler. En konkret anbefaling var, at underviseren skal være fysisk tilstede ligeligt på skift mellem lokalerne i parallelundervisning. Dette er siden indført som et princip, og i Fleksibel hf, dvs. Global Classroom setup, kræver vi, at de studerende møder op i det fysiske klasselokale regelmæssigt. I øjeblikket er det en gang ugentligt.

- Underviseren og ledelsen skal give mulighed for øget samarbejde mellem undervisere, fordi den enkelte underviser med ét får kolleger på to afdelinger, som skal inddrages i organisering, planlægning og fællesskab omkring pædagogiske principper og praktiske forhold, især:

○ Faglige og pædagogiske målsætninger

- Metodiske valg

- Ansvar for progression i de studerendes studiekompetencer,

herunder læsestrategier, studieteknik og skriftlige arbejder.

Disse punkter er også blevet aktuelle for underviserne, som er i team sammen omkring Fleksibel hf. Kursisterne skal i 
almindelighed, og i særdeleshed med de nye

tilrettelæggelsesformer, mærke konsistens i undervisernes valg af platforme til kommunikation mv.

- Undervisningen skal sekventeres, dvs. hellere korte intensive blokke end lange præsentationer, som ikke virker godt via videokonference. Lange oplæg virker trættende, mens interaktion virker opkvikkende.

- De interaktive tavler, som også er bundet sammen via netværket, skal anvendes aktivt og gerne af både underviser og studerende i alle lokaler.

- Alt materiale skal være tilgængeligt på skolens learning management system, Fronter. Det giver sig selv, at det er vanskeligt at uddele kopier gennem videoforbindelsen.

- Interaktionen mellem underviser og studerende og mellem rummene skal medieres og faciliteres. Åben debat, hvor den højest talende får ordet virker ikke via et lydanlæg. Digital interaktion i kombination med faciliteret samtale virker godt, men husk at gøre noget aktivt for at engagere de studerende, så faciliteringen ikke blot "dræber" uroen, men også dynamikken.

- Interaktive medier og materialer virker lige godt for alle uanset hvor underviseren befinder sig. Studerende i lokalet og på distancen føler sig lige godt behandlet og med lige mulighed for at kommunikere med de medstuderende og underviseren.

- Undervisningen skal være planlagt i så høj grad, at de studerende ved, hvad de skal arbejde videre med, hvis forbindelsen går ned i kortere eller længere perioder.

Der er senest i 2013 foretaget omfattende ændringer af skolens netværk og ikke mindst en stor opgradering af båndbredden på internetforbindelsen og netværket mellem afdelingerne for at imødekomme behovet for gnidningsfri kommunikation via videokonferenceserverne

Den nye læringsplatform danner baggrund for et EU-projekt i samarbejde med erhvervsskolen CELFii, som også er begyndt at anvende parallelundervisning, og vi har et fælles budget på 24 mio. kr. til implementering af platformen, udvikling af pædagogik og ikke mindst kompetenceudvikling for lærerne. Det overordnede formål med EUprojektet er:

- At skabe nye uddannelsesmuligheder og dermed motivere de unge $\mathrm{i}$ regionen til at gennemføre en ungdomsuddannelse

- At tilrettelægge nye undervisningsformer der, gennem anvendelse af teknologi, skaber sammenhæng i tyndtbefolkede områder

- At give uddannelsesinstitutionerne de nødvendige kompetencer til at kunne tilbyde og afvikle uddannelsestilbud, der tager udgangspunkt i den enkeltes behov og ressourcer.

Parallelundervisning giver åbenlyst mulighed for at gennemføre aktiviteter, som ellers ikke ville være økonomisk mulige, f.eks. højniveaufag og andre 
valgfag med begrænset søgning i hver by. Så i stedet for at aflyse 2 halve hold kan vi gennemføre et helt, men fordelt på to lokaler. Man kunne også vælge at tilbyde de studerende at tilmelde sig samme sted, men det er ikke praktisk muligt når det tager 1 til 2 timer med bus og tog mellem afdelingerne. Med parallelundervisning kan vi teoretisk set tilbyde alle fag overalt, selv om det naturligvis giver lidt skematekniske udfordringer.

Global Classroom handler om at give den enkelte studerende ekstra fleksibilitet. Målgruppen er unge voksne på hf2, dvs. fuldtidsstuderende på gymnasialt niveau, som af mange forskellige årsager kan have behov for fleksibilitet. I de klasser der har gennemført og er i gang har vi studerende med særlige behov. F.eks. (enlige) forældre eller studerende som af psykiske årsager har svært ved at deltage hver dag i klasselokalet sammen med mange andre. Flertallet $i$ klasserne er almindelige unge voksne, og alle er optaget på hf efter samme retningslinjer som alle andre i VUC systemet. Der er altså ikke tale om specielt fagligt svage eller specielt fagligt stærke studerende, og vi målretter ikke hverken markedsføring eller indhold til særlige målgrupper. Det havde vi ellers fra starten troet vi skulle/kunne. Ambitionen var at tiltrække studerende med særlig interesse for kreative fag, f.eks. studerende med ambitioner om optagelse på musikkonservatoriet. Vi ville så kombinere tre tilrettelæggelsesformer: 1: Holdundervisning, dvs. traditionel klasseundervisning, 2: Global Classroom, dvs. synkron fjernundervisning og 3: Traditionel fjernundervisning, dvs. asynkron fjernundervisning (figur 3). Det 3. element ville give de studerende en ugentlig skemafri dag, som de kunne anvende til musikundervisning på musikalsk grundkursus, MGK.

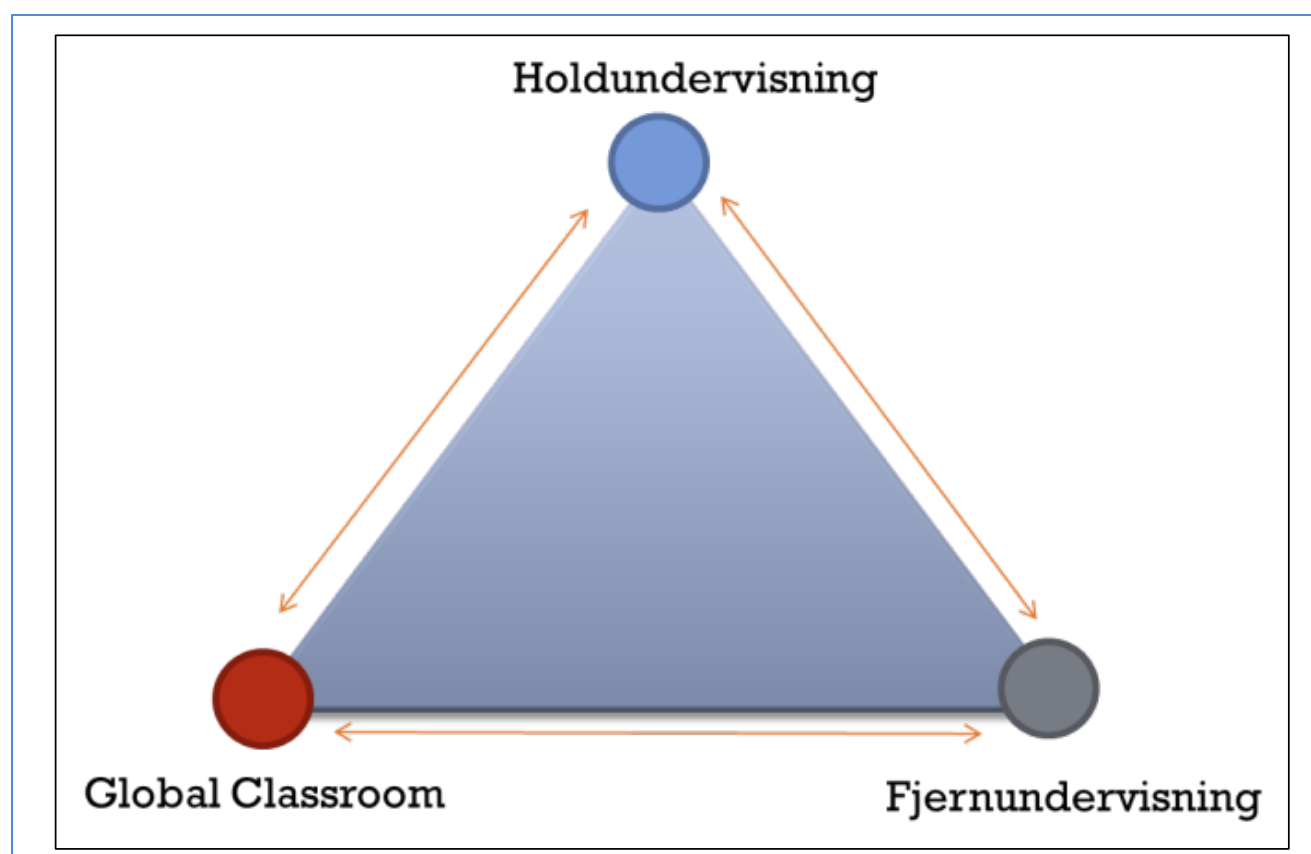

Figur 3. Vekselvirkning mellem 3 tilrettelæggelsesformer. 
Vi mener forsat, at en dynamisk vekselvirkning mellem tilrettelæggelsesformerne vil fremme de studerendes udbytte. Traditionel holdundervisning er velegnet i situationer, hvor opbygning af sociale relationer er vigtig. F.eks. ved opstart af nye hold og ved længerevarende/dybtgående evalueringer, hvor de studerende skal støtte hinanden. Asynkron fjernundervisning er i øjeblikket ikke et selvstændigt element, som afløser lektioner, men e-læringsobjekter fra fjernundervisning anvendes i stigende grad, ikke mindst screencasts og videoklip anvendes med inspiration fra erfaringerne med konceptet Flipped Classroom (se videoerne hjemme og arbejd med opgaver/projekter i skolen).

Arbejdet med udviklingen af parallelundervisning og Global Classroom har givet VUC Storstrøm nye samarbejdsformer og relationer til nye samarbejdspartnere, som er en stor hjælp og inspiration. Studerende, undervisere, IT-pædagogiske konsulenter og eksterne samarbejdspartnere bidrager til at definere behov og finde innovative løsninger, der imødekommer de pædagogiske behov for udvikling af undervisningen i den nye teknologiske ramme. Samarbejdet er helt afgørende for den enkelte undervisers mulighed for at arbejde innovativt.

Vi samarbejder med eksterne konsulenter og forskere, bl.a. Karin Levinsen og Rikke Ørngreen fra Aalborg Universitet, København om kompetenceudvikling af lærerne, og der er tilknyttet en Ph.d. studerende, Charlotte Lærke Weitze, til at følge udviklingen i Global Classroom.

VUC Storstrøm var nomineret i to kategorier i United States Distance Learning Award 2013iii, og fik i april 2013 sølvmedalje for udvikling og implementering af Global Classroom i den ene kategori.

4. april 2013 åbnede VUC Storstrøm Center for anvendt IKT ${ }^{\text {iv }}$ sammen med RUC, UC Sjælland, CELF og Lolland Kommune, hvor lærere på tværs af uddannelsessektoren kan mødes og berige hinandens udvikling.

\section{Det overordnede formål med avanceret teknologi i undervisning}

På VUC Storstrøm er vi af den opfattelse, at skolen ikke blot skal afspejle det omgivende samfund og levere sin del af den uddannelsesmæssige opgave i forhold til samfundets oplevede behov. Skolen skal også motivere, inspirere og dygtiggøre deltagerne i forhold til at indgå i udviklingen af samfundet, og vi må derfor kontinuerligt vurdere, hvilke megatrends der er relevante for os. Det gælder naturligvis på det faglige og metodiske plan, hvor ministerierne og politikerne giver specifikke mål og rammer, men det gælder også i forhold til det, vi vælger at kalde praksislæring, som også omfatter alt det andet vores børn og unge voksne lærer af omstændighederne omkring undervisningen. F.eks. lærte jeg i skolen at se 
engageret ud, for så troede læreren, at jeg havde forberedt mig og spurgte så en anden. Jeg lærte også at skrive på en kridttavle, og at gode matematikkundskaber var vigtige. For så ville de søde piger vælge at sidde ved siden af en, når vi skulle løse opgaver sammen. Det nærmeste vi kom på IT-kompetencer var at iagttage lærerens arbejde med smalfilmsapparatet, når vi skulle se BP-filmen om olieudvinding i Alaska. Fra den situation lærte jeg nu mest, at timing er rigtig vigtig, hvis man skal fyre vittige bemærkninger af. I skolen lærer vi således at socialisere og interagere, men vi lærer også at arbejde inden for et pædagogisk miljø - i mit tilfælde symboliseret ved kridttavlen.

Ser vi på det med at lære ved at arbejde, praksislæring, så var der i 60'erne og 70'erne stor forskel mellem lærerens og de undervistes arbejdsform. Hele læringssituationen var veldefineret og nærmest naturlov på niveau med tyngdekraften, fordi underviserens autoritet var det bærende element i positionen som lederen i klassen. Vores rolle og arbejdsform som elever/studerende var nem at forstå for os, der var socialiseret i miljøet, men det var (er fortsat?) en del af skolen, som ikke var (er) i overensstemmelse med udviklingen i størstedelen af det omgivende samfund.

Spørgsmålet er, hvordan uddannelsessystemet i dag matcher det øvrige samfunds anvendelse af IKT? og ad hvilke veje vi skal gå for at nå dertil? Ser vi bort fra de egentlige IT- og IKT-uddannelser, er der på mange uddannelser ikke længere selvstændige IT-fag, som kan være grundlag for de studerendes anvendelse af IKT i deres øvrige studie. De tilbageværende IT-fag er groft sagt enten meget grundlæggende eller målrettet kompetencer, der skal give forudsætninger for at læse videre på uddannelser indenfor IT/IKT. VUC s uddannelser giver adgang til videre studier i bred forstand, og vi mener, at de studerendes IKT kompetencer skal udvikles ud fra deres praktiske anvendelse af IKT i alle fag. Vi introducerer naturligvis til forskellige systemer og programmer, som anvendes i undervisningen, men kompetencerne skal komme gennem praksislæring. Her er den generelle udvikling med os. Først og fremmest føler vores undervisere et fællesskab med de studerende, og har ikke behov for at markere en tydelig afstand mellem underviser og studerende gennem arbejdsformen. $\mathrm{Nu}$ arbejder vores studerende med inspiration fra undervisernes arbejde med egen faglighed og læringsmetode, hvorfra underviseren genererer eksempler på, hvordan man kan efterspørge specifik viden og arbejde sig frem til løsninger og indsigt. Det betyder, at underviserne også i forhold til IKT kompetencer er helt afgørende som rollemodeller for de studerendes praksislæring. De studerende opnår naturligvis også IKT kompetencer på mange andre måder uden for undervisningen, men undersøgelser viser, at det ikke nødvendigvis er kompetencer de studerende kan, eller tænker på, at anvende på studiet (Levinsen, K \& Ørngreen, R (2012)). Vi har også eksempler på det 
modsatte, hvor studerende kompenserer for fejl i vores IKT-system med alternativer på eget initiativ, det vender vi tilbage til.

De studerende anvender, som alle vi andre, ofte IKT uden for undervisningen, og en del af det bringer de med ind $\mathrm{i}$ undervisningssituationen. Vi hængte i starten skilte op med teksten "Sluk mobilen", men det giver ikke mening længere, det er langt bedre at udnytte de studerendes IKT til at berige undervisningen. De sociale digitale netværk er åbenlyst meget motiverende, og de viser, hvor meget lyst vi har til at relatere os til hinanden kloden rundt. Motivation, relationer og underholdende elementer kan fremme læring og kompetenceudvikling, og det skal vi benytte os af. Ved at inkludere de studerendes medbragte smartphones, tablets og pc'ere i undervisningen, får vi deres opmærksomhed, som også er en væsentlig faktor for deres udbytte af undervisningen.

Endelig er formålet med at integrere avanceret teknologi bredt i fagene, at vi kun i begrænset omfang kan give undervisere og studerende de rette IKT kompetencer uden for den almindelige undervisning. Det vil kræve en enorm ressourceindsats, hvis det skal foregå som traditionelle kurser og efteruddannelse. Dels skal alle opnå et relativt højt niveau, og dels går IKTudviklingen, især inden for programmer, hurtigere end vi kan nå at efteruddanne underviserne. VUC Storstrøm ønsker desuden en bottom-up drevet udvikling i anvendelsen af nye programmer.

Summa summarum er formålene med at anvende avanceret teknologi i undervisningen:

- at skolen er med i samfundets udvikling i anvendelsen af IKT i modsætning til at halte bagefter

- at de studerende skal opnå kompetencer til videre uddannelse og arbejde

- at de studerendes sunde interesse og fascination at IKT inkluderes og omsættes til læring

- at bruge interessante/spændende teknologier i udviklingen af læringsmiljøet

\section{Diskurs om modstand}

Underviserne er vidensmedarbejdere og skolens vigtigste udviklingsressource, som skal kunne gå på opdagelse i mulighederne i IKT. Underviserne er i forskellig grad begejstrede for digitale elementer og tilrettelæggelsesformer med anvendelse af videokonference, men vi oplever stort set ikke egentlig modstand, når vi udvikler og taler sammen. Der er en positiv holdning til ny IKT, også selv om det nogle gange kan virke som en meget stor mundfuld, hvis man ikke i sin egen uddannelse har benyttet moderne IKT. Holdningerne er i orden, vi er motiverede, men 
alligevel oplever vi næsten alle en gang i mellem en indre modstand. Jeg kan ikke tale for andre end mig selv i dette forhold, men min oplevelse kan måske sætte ord på et fænomen, vi også skal være opmærksom på, nemlig forestillingen om god undervisning, som den ligger indlejret i vores inderste, dvs. i selve sproget. Tager jeg ordet "undervisning" i nærmere øjesyn, så kan jeg godt opstille nogle principper for, hvad jeg bevidst mener, at god undervisning er. Jeg kan endda argumentere og henvise til undersøgelser, men jeg er også sikker på, at der langt inde i underbevidstheden hænger et billede af 1.b, hvor jeg startede min skolegang i 1966 på Abildhøjskolen. Det var en lykkelig og tryg tid, og neden under billedet står "Skole". Lidt karikeret vil jeg sige, at jeg bevidst kan tænke mig frem til hvad god undervisning er, men underbevidstheden vil meget gerne holde fast $\mathrm{i}$ begrebet skole $(=1 . b)$, som selve definitionen på undervisning. Dermed ikke sagt, at alle mine begreber om undervisning kan dateres til 1966. Pointen er blot, at mine reflekser, og vaner, har rod i mine egne oplevelser som elev. Hvis jeg kommer under pres, så kan jeg underbevidst finde på at søge tilbage til en adfærd, der passer til mine grundlæggende definitioner. Skal vi undgå, at min indre, potentielle modstand bliver dominerende, skal den bearbejdes gennem refleksiv praksis, og omgivelser skal acceptere, at det kan tage tid.

Omsat til handling betyder det, at man ikke udefra skal presse undervisere til at anvende nye digitale elementer og f.eks. Global Classroom i et bestemt system uden refleksion over egen praksis. Det handler heller ikke kun om at etablere en konsensus i et underviserteam. Den enkelte underviser skal kunne reflektere over egen praksis, have et tilstrækkeligt teoretisk ITpædagogisk fundament og en personlig motivation til forandring.

\section{Forudsætninger for implementering af videokonference i undervisning}

Som nævnt indledningsvis, så må man nødvendigvis forsøge at kigge ind i fremtiden, hvis man vil investere i ny teknologi. Som Nils Villemoes siger i et underholdende videoklip på Youtube, så sidder vi "helt stille og forestiller os, at verden er helt anderledes end den er". Det er lidt karikeret, men indeholder også en vis sandhed. Hvis vi vil være med til at præge fremtidens undervisning, kan vi ikke kun kigge bagud - visioner er nødvendige. Vi er i dagligdagen meget praktisk anlagte, og vores tilgang er anvendelsesorienteret. Det gælder almindeligvis også for VUC Storstrøms pædagogiske udvikling og de implikationer, den har for vores anvendelse af IKT. Men vi ser naturligvis også på forskningsresultater og erfaringer formidlet gennem de netværk VUC Storstrøm deltager i. Det sætter vores praksis i perspektiv, og samfundets idealer om god undervisning præger naturligvis også os. Vores målgrupper er uhomogene, såvel på tværs af uddannelserne som inden for den enkelte uddannelse, og vores undervisere skal møde en palette af forskellige læringsstile og 
uddannelseserfaringer i hver enkelt klasse. Vores studerende er mellem 18 og 30 år, og de fleste kan betegnes som unge voksne. De har i forskellig grad typisk afbrudte uddannelsesforløb bag sig, eller de har efter endt erhvervsuddannelse fået mere lyst til en uddannelse i boglig retning. De studerendes studietekniske forudsætninger er på meget forskelligt niveau, og det er deres sociale kompetencer også. Nogle er selvmotiverede, og andre møder op med et uddannelsespålæg fra jobcentret. Det samlende er fra starten, at de er voksne i et voksent miljø, og efterhånden opbygger de sammen med underviserne et undervisningsmiljø med flere samlende elementer, socialt og fagligt.

VUC Storstrøm er med disse udfordringer og med den særlige opgave i uddannelsessystemet meget opmærksom på, hvordan vi kan medskabe vores fremtid. Med vores uddannelsestradition i bagagen, med alt hvad vi har lært fra andre, og fra en position midt i lyskrydset, stiller vi os på taget af bussen og ser ud i horisonten. Når vi har dannet os et godt billede af den aktuelle (!) fremtid, går vi ned i bussen og beslutter, hvilken retning vi skal køre i. Fremtidssikring findes ikke, men ved at have en langsigtet vision og strategi kan vi efterhånden kvalificere os og blive kompetente til at træffe beslutninger om IKT. VUC Storstrøm har arbejdet med ny-teknologiprojekter siden starten af 1990'erne, så vi er ved at have øvelsen.

Forudsætning 1 er således, at vi kompetent kan træffe visionære beslutninger om IKT, der dækker investeringshorisonten. Konkret vil det for videokonferenceudstyr være ca. 5 år, eller lidt længere end afskrivningsperioden på 3 år. Vi har i den sidste investering i udstyr til Global Classroom været begunstiget af et stort bidrag fra EU's Socialfond, som har muliggjort projektet "Den ny læringsplatform". Det har gjort beslutningen mulig, men visionen og strategien er forsat afgørende, idet teknologien er implementeret direkte i driften. Det er med andre ord ikke et forsøg ved siden af undervisningen, det er selve undervisningen, der drives i den nye platform og de første hf-studenter fik hue på denne sommer.

Vi skal også kompetent kunne vurdere, hvordan en satsning på IKT sporet vil påvirke andre strategiske hensyn. VUC Storstrøm har et værdigrundlag og en række pædagogiske principper, som er udviklet gennem årene i samarbejde mellem undervisere, interne konsulenter og ledelsen. Det kan være endog meget vanskeligt at gennemskue, hvordan videokonference og dermed fysisk adskillelse mellem underviser og (nogle af) de studerende influerer på væsentlige pædagogiske principper, som f.eks. undervisningsdifferentiering på basis af forskelle i læringsstile, eller inkludering af flere gennem styrkelse af personlige relationer. Ideelt set, skal nye tiltag i så kort tid som muligt være et tillæg til det eksisterende, og hurtigst muligt skal det nye element indgå i det samlede "naturlige" læringsmiljø. 
Forudsætning 2 er således, at vi kan designe en udviklings- og implementeringsperiode, hvor underviserne har mulighed for at deltage i og bidrage til den konkrete anvendelse af videokonference. Derefter er videokonference et vilkår, som indgår i lighed med vilkår, som hidrører fra andre mål og prioriteringer.

I forhold til den almindelige IT-drift har de fleste skoler opgaver, man løser i huset med eget personale og opgaver, der løses af konsulenter udefra. Her er det rigtig vigtigt, at videokonference ikke ligger i naturlig forlængelse af de IT-systemer, man ellers har i skoler. Erfaringerne fra alle vi har kendskab til er, at videokonference har væsentlig større og bredere betydning for den øvrige IT-drift end først antaget. Derfor er det ikke sikkert, at hverken interne eller de sædvanlige eksterne IT funktioner er tilstrækkeligt kompetente til samspillet med leverandøren - og det gælder helt fra udformningen af kravspecifikationen (som vi foretrækker at kalde for funktionsbeskrivelsen) til den løbende servicering af lokaler, undervisere og studerende, når den udfordrende implementeringsperiode er gennemført.

Forudsætning 3 er således, at vi kompetent kan udforme funktionsbeskrivelser, vælge leverandør og evt. samarbejdspartnere, og at vi kan udvikle interne/indkøbe eksterne kompetencer til gennemførelse af implementering og efterfølgende løbende servicering.

\section{Hvilke resultater har vi opnået med videokonference?}

Fra vi startede med parallelundervisning i 2009 har over 1000 studerende gennemført et enkeltfag på hf, og i Global Classroom har pionererne på Fleksibel hf fra skoleåret 2011/2012 gennemført deres fuldtids hf2 i juni 2013. I øjeblikket (efteråret 2013) har vi en række enkeltfag som parallelundervisning mellem to afdelinger, og vi har 2 hold fuldtids hf2 studerende på afdelingen i Nykøbing F. Vi har altså integreret videokonference i den almindelige drift, og det er en meget væsentlig målsætning der er indfriet. Fra august 2014 bliver omfanget af fleksibel hf fordoblet, idet afdelingen i Næstved til den tid også udbyder hf i Global Classroom setup.

Forskere og phd studerende fra Aalborg Universitet følger Global Classroom og specialestuderende fra Aarhus Universitet følger eller har fulgt Global Classroom og en specialestuderende fra IT Universitet/AAU fulgte parallelundervisningen i sidste skoleår. Desuden er Teknologisk Institut tilknyttet det EU støttede projekt "Den ny læringsplatform" som evaluatorer. Vores erfaringer og input fra forskere og studerende er grundlag for de følgende 3 afsnit. 


\section{Implementering i organisationen}

IKT-mæssigt er vi på plads og via "learning by doing" ved vi nu, hvilke kompetencer der er nødvendige i IT-afdelingen. Kompetencerne går i to spor: 1) Implementering af udstyr i de centrale IT-faciliteter (servere, internt netværk og eksternt netværk), og 2) Servicering af undervisere, studerende og administrationen. Som nævnt er den tekniske del meget kompliceret, og svært forudsigelig, men det er ikke emnet for denne artikel. I forhold til servicering opstår en ny situation med videokonference, fordi undervisningen bliver meget udfordret, hvis teknikken svigter. Når vi ikke arbejder med videokonference kan IT-fejl rettes på et senere tidspunkt, men når undervisningen afvikles i Global Classroom eller parallelundervisning, så mister underviseren og de studerende kontakten, hvis forbindelsen bliver afbrudt. Der er derfor etableret nye rutiner for servicering af Global Classroom med en særlig hotline. Erfaringerne er overraskende og udfordrende! Fra en særlig tilrettelagt intern evalueringsdag og fra den løbende dialog med underviserne ved vi (Weitze, C; Ørngreen, R \& Levinsen, K (2013) s.506), at de studerende oplevede problemer og også følte, at deres henvendelser om disse problemer ikke blev taget alvorligt. Omvendt har IT-afd. og projektledelsen ikke registreret andet end nogle få henvendelser, og dem er der blevet fulgt op på.

Organisationen har naturligvis hørt om problemerne, men der er en særlig udfordring ved tekniske problemer med videokonference, fordi nedbrud i forbindelser ikke efterlader spor. Fra starten af skoleåret 2013/2014 tilbringer IT-teknikerne derfor mere tid synligt sammen med klasserne. Et andet resultat er, at kravene til udstyr i klasserne og hjemme hos de studerende er blevet tydeligere. Vi har også intensiveret overvågningen af det tekniske udstyr, og det har afhjulpet de fleste problemer. Et særligt aspekt er, at nogle at problemerne opstår hjemme hos de studerende, og vores IT afdeling arbejder normalt ikke med servicering af studerende på deres private netværk.

Skemalægning og ressourcestyring fylder jo en del i de fleste skoler, og parallelundervisning og Global Classroom bidrager også til festen her. Det er helt afgørende for resultatet, dvs. de studerendes udbytte af undervisningen, at beslutningen om anvendelse af videokonference i undervisning bliver taget i god tid, og ikke som en nødløsning i sidste øjeblik. Underviserne skal gives god mulighed for at opleve den nye læringssituation og tid til at udvikle undervisningsplaner. De studerende bør også allerede ved valg af uddannelse have information om tilrettelæggelsesformen, så de ikke oplever f.eks. parallelundervisning som en nødløsning.

Det er egentlig ikke et tema for denne artikel, men der er også økonomiske konsekvenser i begge retninger, som vi har gjort en del erfaringer med. 


\section{De studerendes udbytte af Global Classroom}

Som nævnt har de studerende fået tilstrækkeligt udbytte til at kunne gennemføre 1. år hhv. hele uddannelsen på fleksibel hf. Vi har ikke hørt om studerende, der har forladt studiet eller klandret tilrettelæggelsesformen for ikke at give tilfredsstillende undervisning.

De studerende finder motivation gennem deres personlige stillingtagen til, om de vil deltage i klasserummet eller via videokonferencen. Det giver en oplevelse af frihed (Weitze, C; Ørngreen, R \& Levinsen, K (2013), s. 505f). Fra interview med studerende på første årgang ved vi, at de enlige forældre føler et mindre pres og kan tildele undervisningen mere opmærksomhed, især på lange dage med undervisning fra 8 til 16. Det skal med i betragtningen, at begge de enlige forældre havde min. $1 / 2$ times transport hver vej. Studerende nævner også, at de kan skifte miljø midt på dagen, hvis de føler for det, og det giver mere variation (ibid, s.4). VUC Storstrøm har som andre skoler udfordringer i forhold til frafald. Nogle studerende, og heldigvis de fleste, er målrettede og har inden start på hf2 klar ide om, hvilken videregående uddannelse de vil søge ind på. Andre er knapt så selvmotiverede, og så skal der ind i mellem ikke så voldsom meget snue til, før man vælger at blive hjemme. Nogle af disse vælger at følge hele dagens undervisning hele eller en del af denne via videokonference i stedet for at melde helt fra. En ubevidst sidegevinst er, at det også giver en debat $\mathrm{i}$ klassen om, hvordan man skal/bør deltage i undervisningen. Bedømt på udsagnene på en evalueringsdag, så er der et generelt ønske om, at man som studerende skal være aktiv både i klasserummet og hjemme. Det tyder på, at vi også får det udbytte, at de studerende forholder sig til deres egen læringssituation og til hele læringssituationen. Vi skal så være forberedte på, at de også forholder sig til den enkelte undervisers præstation, og til de teknologiske omstændigheder, og vi skal kunne honorere deres engagement ved at håndtere de problemer, de påpeger.

De studerende påpeger bl.a. at nogle undervisere ikke er opmærksomme nok på kursisterne hjemme.

Som en særlig sideeffekt af nogle tekniske problemer fandt nogle af de studerende nye kommunikationskanaler og former, som alternativer til videokonferencen. Det kunne være facebook og e-mails, som uden om læreren holdt studerende hjemme i kontakt med klasse via deres medstuderende i klassen.

Efter lang tids dialog og forsøg på at opstille specielle adfærdsregler for hjemmesiddende studerende på fleksibel hf, besluttede vi, at reglerne skal være de samme for alle studerende i klassen, som hjemme. Det vil f.eks. sige, at man skal være påklædt, man må ikke ryge, og man må ikke medbringe husdyr, som forstyrrer undervisningen. 
De studerende er glade for nye digitale elementer og specifikt nævner de i evalueringen "learning designs that involve work on the Internet, as this gave equal opportunities for students at home and on campus" (ibid s.4)

Adspurgt om en samlet vurdering siger de studerende, at Global Classroom er en fordel, og de ønsker at fortsætte i klassen (ibid s.5).

\section{Undervisernes udbytte af Global Classroom}

Vi startede "blødt" i efteråret 2011 med en relativt lille klasse pionerer. Klassens størrelse og en meget gradvis og fleksibel ibrugtagning af videokonference gjorde, at vi kunne følge op på de problemer, der skulle vise sig. En gruppe af underviserne arbejdede allerede fra efteråret 2010 med udvikling af konceptet Kreativ, fleksibel hf. Alligevel havde vi ikke ved starten i august 2011 alt pædagogisk på plads. Forandringen fra traditionel undervisning til, at nogle af kursisterne efter eget valg kunne blive hjemme og deltage i undervisningen via pc, var for abstrakt, så længe underviserne ikke havde prøvet det.

Mange af underviserne fra den første klasse var med igen det første år i den anden klasse. Alligevel oplevede vi ret store tekniske problemer andet år, og på en helt anden måde end forventet. Problemer vi havde løst første år kom tilbage, og det viste sig efterhånden, at vi havde udfordringer med netværket, fordi der nu var langt flere samtidige brugere. Problemerne blev efterhånden løst, bl.a. gennem en kraftig opgradering af båndbredden. De tekniske forhold og måske usikkerheden omkring teknologien har naturligt fyldt meget i undervisernes bevidsthed. Der er dog også for de fleste underviseres vedkommende en nysgerrighed om mulighederne i digitale virkemidler og medier, og de er opmærksomme på, at de studerende sætter pris på fleksibiliteten. Der er generelt en stor opmærksomhed omkring sårbare kursister, frafald osv. og underviserne håber på, at fleksibiliteten vil få flere til at fortsætte på de uddannelser, de starter på.

Underviserne oplever, at de skal tage deres pædagogiske metoder op til overvejelse, fordi en række forhold er ændrede. F.eks. skal gruppearbejde organiseres anderledes, og det kan være svært at bruge kropssprog og mimik. Alligevel fremhæver underviserne, at den generelle oplevelse er, at de godt kan fortsætte deres undervisning nogenlunde som i andre klasser.

\section{Hvordan kommer vi videre?}

Vi fortsætter indsatsen for at udvikle undervisernes innovative kompetencer. Det er ikke kun nødvendigt, fordi vi anvender videokonference, men en naturlig konsekvens af de store forventninger til uddannelsessektoren, f.eks. målet om, at 95\% skal gennemføre en ungdomsuddannelse. For mange er VUC den oplagte mulighed for at komme tilbage i uddannelsessystemet, og som nævnt kommer vores deltagere med vidt forskellige baggrunde. Desuden underviser vi på 7 
forskellige niveauer + ordblindeundervisning, forberedende voksenundervisning (FVU) og andre studiestøttende tilbud. Vi er vant til at søge alternative veje for at møde målgruppernes behov, og undervisernes innovative kompetencer er helt afgørende også i den sammenhæng. Når vi dertil lægger en ny fysisk ramme, som videokonference, ind som et nyt vilkår bliver innovation endnu mere central for kvaliteten i undervisningen.

I parallel-undervisning er der gjort forsøg med netbaseret chat og digitale "række-hånden-op" faciliteter (Exner, M (2013), s. 68ff). Vi fortsætter med introduktion af digitale kommunikationsformer til støtte for kommunikationen mellem 2 eller flere adskilte lokaler. Vi gør det primært af praktiske årsager, men også for at udforske, hvordan etablering og vedligeholdelse af personlige relationer kan ske i et virtuelt miljø. Vi arbejder jo med en generation der er "på" $24 / 7$,så der er bestemt et potentiale.

Det er vores idé, at undervisningen kan gøres endnu mere interessant og differentieret ved at inddrage flere digitale elementer, som også påpeget i forskningen (Levinsen, K \& Ørngreen, R (2012), s.3). Vi mener også, at det er nødvendigt at revitalisere undervisernes samarbejde om udvikling af læringsdesign. Den enkelte kan have svært ved at indoptage de mange forskellige digitale muligheder og anvende dem i udviklingen af undervisningen. AAU's og VUC Storstrøms fælles phd-projekt, som løber til og med 2015, handler netop om udvikling af undervisernes innovative kompetencer, individuelt, men i høj grad også i fællesskab. Som en ekstra udviklingsmotor og videnkilde inviterer vi sammen med RUC, UCSJ, Lolland Kommune og CELF interesserede undervisere og udviklere til fælles kompetenceudvikling i Videncenter for anvendt IKT.

Vi arbejder i videncentret og på egen hånd også videre med andre features og designs, som kan forbedre de studerendes udbytte og give underviserne flere spændende elementer at arbejde med, f.eks.:

- Digital vejledning, synkront og asynkront

- 3D elementer med "billige" kameraer

- Global Guest Teacher

Interesserede er velkomne til at henvende sig for yderligere information. 


\section{Litteratur}

Levinsen K. \& Ørnegrem, R. (2012). Analyse af studerendes IKTkompetencer. På VUC, UC Sjælland og SOSU Sjælland - 2012, Aalborg Universitet, 11. december 2012

Weitze, C; Ørngreen, R \& Levinsen, K (2013). The Global Classroom video conferencing model and first evaluations, i: Proceedings of the 12th European Conference on e-Learning, SKEMA Business School, Sophia Antipolis, France, 30-31 October 2013, Volume Two

Exner, M (2013). Ses vi på de anden side? En designbaseret undersøgelse af interaktionen i den parallelle undervisning ved VUC Storstrøm. Cand.IT speciale, Aalborg Universitet 30. april 2013.

\footnotetext{
' VUC Storstrøm er et voksenuddannelsescenter. Fra 7 steder i kommunerne Faxe, Vordingborg, Næstved, Guldborgsund og Lolland udbydes højere forberedelseskurser (hf), almen voksenuddannelse (op til niveau svarende til 10. klasse), forberedende voksenuddannelse samt ordblindeundervisning.

ii Center for Erhvervsrettede uddannelser Lolland Falster

iii Se mere om USDLA på dette link: http://www.usdla.org/2013-award-winners/

iv Se mere om Center for anvendt IKT på dette link: http://viaikt.wordpress.com/
} 